\title{
Growth curves of different free-range chicken lineages by the Gompertz model
}

\author{
Curvas de crescimento de diferentes linhagens de frangos caipiras por meio do modelo de
}

\section{Gompertz}

Curvas de crecimiento de diferentes linajes de pollos campesino por médio del modelo de Gompertz

Claudson Oliveira Brito

ORCID: https://orcid.org/0000-0002-3339-8647 Universidade Federal de Sergipe, Brasil E-mail: claudson@ufs.br

Janaína Thainara de Lima Maciel

ORCID: https://orcid.org/0000-0002-2078-1639 Universidade Federal de Sergipe, Brasil E-mail: janamaciel8@gmail.com Anderson Corassa

ORCID: https://orcid.org/0000-0002-3969-3065 Universidade Federal de Mato Grosso, Brasil E-mail: anderson_corassa@ufmt.br

Arele Arlindo Calderano

ORCID: https://orcid.org/0000-0002-2282-3580 Universidade Federal de Viçosa, Brasil E-mail: calderano@ufv.br

José Geraldo de Vargas Júnior

ORCID: https://orcid.org/0000-0001-6801-5629

Universidade Federal do Espírito Santo, Brasil E-mail: jose.vargas@ufes.br

Gregório Murilo de Oliveira Júnior

ORCID: https://orcid.org/0000-0001-7391-272X Universidade Federal de Sergipe, Brasil

E-mail: gregoriomurilo@academico.ufs.br

Camilla Mendonça Silva

ORCID: https://orcid.org/0000-0001-5259-9316

Universidade Federal de Sergipe, Brasil

E-mail: camillamsazoo@gmail.com

Leonardo Siqueira Gloria

ORCID: https://orcid.org/0000-0002-2756-5939

Universidade Estadual do Norte Fluminense, Brasil

E-mail: leonardogloria@uenf.br

Débora Cristine de Oliveira Carvalho

ORCID: https://orcid.org/0000-0002-6095-7969

Universidade Federal do Vale de São Francisco

E-mail: debora.carvalho@univasf.edu.br

\begin{abstract}
The knowledge of the dynamics of animal growth over time can be done through non-linear equations. Thus, the objective was to describe and compare the growth of three free-range chicken lineages based on the Gompertz equation. 180 unsexed chickens assigned to three treatments (Pesadão Vermelho, Pescoço Pelado and Carijó Pesado lineages) in a randomized design with six replicates, with 10 birds per experimental unit. Broilers were weighed weekly (until 77 days of age), these data were used to estimate the growth curve and determine the equation parameters $(A, B$ and $C$ ) of model used. The comparison tests between the model parameters for each lineage, demonstrated that it is necessary an equation with different $A, B$ and $C$ parameters for each lineages, the lack-of-fit test was not significant ( $>0.05$ ), therefore, the equations of the model are suitable to describe the growth of the lineages. The Pesadão Vermelho lineages is heaviest at inflection point and earlier (BWe $=1,528 \mathrm{~g}$ at 39 days of age), compared to the Pescoço Pelado ( $\mathrm{BW} e=1,185 \mathrm{~g}$ at 38 days of age) and the Carijó Pesado (BWe $=1,183 \mathrm{~g}$ at 51 days of age) lineage. The adjusted Gompertz curves accurately estimated growth curves of the evaluated line-ages. An equation with different $A, B$ and $C$ parameters is required for each lineage. The Pesadão Vermelho lineage is heaviest at maturity. The Carijó Pesado lineage has a slow growth, with low weight at maturity and the oldest age at maturity.
\end{abstract}

Keywords: Poultry farming; Non-linear equation; Model identity; Growth parameters; Prediction. 


\section{Resumo}

O conhecimento da dinâmica de crescimento animal ao longo do tempo pode ser feito através de equações não lineares. Assim, objetivou-se descrever e comparar o crescimento de três linhagens de frangos caipiras a partir da equação de Gompertz. Foram utilizadas 180 aves distribuídas em delineamento inteiramente ao acaso com três tratamentos (linhagem Pesadão Vermelho, Pescoço Pelado e Carijó Pesado), seis repetições de 10 aves por unidade experimental. As aves foram pesadas semanalmente (até os 77 dias de idade), essas informações foram utilizadas para estimar a curva de crescimento e determinar os parâmetros $(A, B$ e $C)$ do modelo utilizado. Os testes de comparação entre parâmetros demonstram que cada linhagem necessita de uma equação com parâmetros $A, B$ e $C$ diferentes, o teste para a falta de ajustamento não foi significativo ( $p>0,05)$, portanto as equações do modelo são adequadas para descrever o crescimento das linhagens. A linhagem Pesadão Vermelho apresentou maior peso corporal no ponto de inflexão e maior precocidade ( $\mathrm{PC} e=1.528 \mathrm{~g}$ aos 39 dias de idade), comparado a Pescoço Pelado (PCe=1.185 g aos 38 dias de idade) e Carijó Pesado $(\mathrm{PC} e=1.183 \mathrm{~g}$ aos 51 dias de idade). As curvas de Gompertz ajustadas estimaram com acurácia as curvas de crescimento das linhagens avaliadas, assim, é necessária uma equação com parâmetros $A, B$ e $C$ diferentes para cada linhagem. A linhagem Pesadão Vermelho apresentou maior peso à maturidade. A linhagem Carijó Pesado apresentou crescimento menor com baixo peso à maturidade e maior idade à maturidade.

Palavras-chave: Avicultura; Equação não linear; Identidade de modelos; Parâmetros de crescimento; Predição.

\section{Resumen}

El conocimiento de la dinámica del crecimiento animal a lo largo del tiempo se puede realizar mediante ecuaciones no lineales. Así, el objetivo era describir y comparar el crecimiento de tres linajes de pollos campesinos a partir de la ecuación de Gompertz. Se utilizaron 180 aves, distribuidas en tres tratamientos (linajes Pesadão Vermelho, Pescoço Pelado y Carijó pesado) en un diseño aleatorio con seis repeticiones, con 10 aves por unidad experimental. Los pollos fueron pesados cada semana (hasta los 77 días de edad) esta información se utilizó para estimar la curva de crecimiento y determinar los parámetros $(A, B$ y $C$ ) del modelo utilizado. Las pruebas de comparación entre parámetros demostraron que cada linaje necesita una ecuación, con parámetros $A, B$ y $C$ diferentes, y la prueba para la falta de ajuste no fue significativa ( $>0.05)$, las ecuaciones del modelo son adecuadas para describir el crecimiento de los linajes. El linaje Pesadão Vermelho presenta mayor peso en el punto de inflexión y mayor precocidad (BWe=1,528 g a los 39 días de edad), comparado con Pescoço Pelado (BWe=1,185 g a los 38 días de edad) y Carijó Pesado (BWe=1,183 g a los 51 días de edad). Las curvas de Gompertz ajustadas presentaron con exactitud las curvas de crecimiento de los linajes evaluados. Se requiere una ecuación con parámetros $A, B$ y $C$ diferentes para cada linaje. El linaje Pesadão Vermelho tiene el mayor peso a la madurez. El linaje Carijó Pesado presenta un crecimiento lento con bajo peso a la madurez y mayor edad a la madurez.

Palabras clave: Avicultura; Ecuación no lineal; Modelos de identidad; Parámetros de crecimiento; Predicción.

\section{Introduction}

In the last years, there has been a marked growth in free-range poultry farming in alternative production systems (Aisyahet al., 2018; Lemos et al., 2018). This is mainly due to the need for meeting a highly demanding market, which seeks products with organoleptic characteristics distinct from those found in conventional chicken and, which is concerned with animal welfare (Silva et al., 2017; Sousa Júnior et al., 2020).

Alternative production has as a principle the concern for animal welfare since birds conditioned in a semi-intensive system can express their natural behaviors, such as scratch and spreading their wings, which reduces the stress of these animals (Aksoy et al., 2021). This trend has been accompanied by an evolution in the field of genetics, with the emergence of several free-range chicken lineages encompassing characteristics like hardiness and elevated production indices (Del Castilho et al., 2013). However, varying information can be found regarding body growth between these different lineages (Cruz et al., 2018; Ribeiro et al., 2020). Therefore, estimating the growth curve of the chicken lineages used in this production system may allow for the adoption of management practices that optimize meat production, in which the nutritional requirements of each growth phase can be prioritized. In this way, specific feeding programs can be established and the optimum slaughter weight defined (Morais et al., 2015).

It is possible to know the growth dynamics of an animal over time through non-linear equations by using weight-age data, which makes it easier to predict the development of lineages (Tholon and Queiroz, 2009). Several non-linear regression models exist for this purpose; e.g. Brody, Gompertz, Logistic (Souza et al., 2017), Meloun I, Meloun II, Michaelis-Mentem, 
modified Michaelis-Menten, Richards, Schnute, Von Betalanffy and Weibull (Souza et al., 2013; Fradinho et al., 2016). However, many authors have proved that the Gompertz equation is the most suitable to describe the growth of poultry lineages, because it can predict the maximum weight obtained at maturity and the efficiency of weight gain over time (Neme et al., 2006; Narinc et al., 2010; Sakomura et al., 2011; Grieser et al., 2015).

In this scenario, predicting the body development of different free-range chicken lineages may assist the producer in choosing the lineages to be farmed, indicating genotypes with potential for increased weight at younger ages. This is based on important information such as the period of maximum feed intake, weight at maturity, feed conversion, daily weight gain estimate, among others. Therefore, the present study was carried out to describe and compare the growth curves of three freerange chicken lineages Pesadão Vermelho, Pescoço Pelado and Carijó Pesado based on the Gompertz equation and to check the equality of equation parameters as well as determine whether there is identity in the model used for the three lineages.

\section{Methodology}

\subsection{Ethical considerations}

All experimental procedures were approved by the Ethics Commission on the Use of Animals (approval no 3/2012).

\subsection{Location, animals, experimental design and diets}

The experiment was developed in São Cristóvão city - Sergipe, during the months of june to august 2012. A total of 180 chicks, males and females, with one day old, $\pm 33 \mathrm{~g}$ average initial weight were used in the study. The birds were housed until 28 days of age in an experimental shed build of concrete floor and wood shavings, containing drinkers, feeders, and heating source (infrared electric brooder). After this period the birds were transferred to the free-range poultry sector in the semiconfinement system (Moyle et al., 2014), with free access to paddocks (1.5 x 12m) during the day and collected at night. The sector is characterized by a warehouse with an internal area of $39 \mathrm{~m}^{2}$, covered with fiber cement tiles, with ceiling height of $2.90 \mathrm{~m}$. The warehouse was divided into 18 boxes of $2.16 \mathrm{~m}^{2}$ each $(1.5 \times 1.44 \mathrm{~m})$. All boxes were equipped with a pendant water cooler and a tubular feeder of $20 \mathrm{~kg}$ capacity.

The birds were separated into homogeneous lots according to their average weight $(859 \mathrm{~g} ; 745 \mathrm{~g}$ and $436 \mathrm{~g}$, respectively to Pesadão Vermelho, Pescoço Pelado and Carijó Pesado lineages) and distributed in a randomized block design was adopted design with three treatments, six replicates with 10 birds per experimental unit (box), totaling 60 birds per evaluated lineage. The treatments were represented by the Pesadão Vermelho (CPK), Pescoço Pelado (PSC) and Carijó Pesado (CJD) lineages.

A two-phase feeding system was adopted, in which the starter phase was considered from 1 to 28 days of age and the grower phase from 29 to 77 days of age, as practiced by Sagrilo et al. (2003). In the period from 1 to $28 \mathrm{~d}$ of age, all the birds received a diet containing $22 \%$ crude protein (CP), 2,950 of metabolizable energy (ME) kcal/kg, $1.20 \%$ of digestible lysine (dig. Lys), $0.94 \%$ calcium, and $0.42 \%$ available phosphorus. From 29 to $77 \mathrm{~d}$ of age broilers received diets containing $18 \% \mathrm{CP}, 3,050$ $\mathrm{kcal}$ of ME $/ \mathrm{kg}, 1.21 \%$ of dig. Lys, $0.94 \%$ calcium, and $0.42 \%$ available phosphorus. The diets were formulated to approximate the nutritional requirements of broilers, initial and grower phase, according to Rostagno et al. (2011).

Chicks were weighed weekly $(1,7,14,21,28,35,42,49,56,63,70$, and 77 days of age) to estimate body weight and daily weight gain. Feed and water were available ad libitum throughout the experimental period.

\subsection{Statistical analyses}

The non-linear Gompertz model was used to estimate the birds body growth curve, as shown below:

$$
Y=A \cdot e^{-e^{-B(t-C)}}
$$


Where:

$Y=$ Estimate of body weight at time $t(\mathrm{~g})$

$A=$ Estimate of weight at maturity (g)

$B=$ Relative growth rate at the inflection point (g/day per $\mathrm{g}$ )

$t=$ Age (days)

$C=$ Age at the inflection point (days), or at maximun growth

$t=A g e$ (days)

$e=2.718281828459$

The model parameters $(A, B$ and $C$ ) for each lineage were adjusted by the PROC NLIN procedure of SAS (version 9.0; SAS Institute, Inc Cary, NC, 2001), using the Marquardt interaction algorithm. The initial parameter values were obtained from Michalczuk et al. (2016). Subsequently, parameter equality and model identity were checked to determine whether a single curve would be adequate to describe the growth of the CPK, PSC and CJD birds.

The likelihood ratio test with approximations given by F statistics (Regazzi and Silva, 2004; Ribeiro et al., 2020) was applied, using the PROC NLIN procedure of SAS software (version 9.0; SAS Institute, Inc Cary, NC, 2001). The unrestricted NLIN procedure, called full model $(\Omega)$, and the model with restrictions (specified by $\omega 1$ or H01; $\omega_{2}$ or H02; $\omega 3$ or H03; $\omega 4$ or $\mathrm{H} 04 ; \omega 5$ or $\mathrm{H} 05 ; \omega 6$ or $\mathrm{H} 06 ; \omega 7$ or H07) were run to obtain the necessary estimates to execute the statistical test of the evaluated hypotheses, for all evaluated lineages (Table 1).

Table 1. Hypotheses considered*.

\begin{tabular}{cc}
\hline Null hypothesis & Alternative hypothesis \\
\hline $\mathrm{H} 0(1): \mathrm{A} 1=\mathrm{A} 2=\mathrm{A} 3=\mathrm{A}$ & Not everyone $\mathrm{A}$ is the same \\
$\mathrm{H} 0(2): \mathrm{B} 1=\mathrm{B} 2=\mathrm{B} 3=\mathrm{B}$ & Not everyone $\mathrm{B}$ is the same \\
$\mathrm{H} 0(3): \mathrm{C} 1=\mathrm{C} 2=\mathrm{C} 3=\mathrm{C}$ & Not everyone $\mathrm{C}$ is the same \\
$\mathrm{H} 0(4): \mathrm{A} 1=\mathrm{A} 2=\mathrm{A} 3=\mathrm{A}$ & At least one equality is an inequality \\
$\mathrm{B} 1=\mathrm{B} 2=\mathrm{B} 3=\mathrm{B}$ & \\
$\mathrm{H} 0(5): \mathrm{A} 1=\mathrm{A} 2=\mathrm{A} 3=\mathrm{A}$ & At least one equality is an inequality \\
$\mathrm{C} 1=\mathrm{C} 2=\mathrm{C} 3=\mathrm{C}$ & \\
$\mathrm{H} 0(6): \mathrm{B} 1=\mathrm{B} 2=\mathrm{B} 3=\mathrm{B}$ & At least one equality is an inequality \\
$\mathrm{C} 1=\mathrm{C} 2=\mathrm{C} 3=\mathrm{C}$ & \\
$\mathrm{B} 0(7): \mathrm{A} 1=\mathrm{A} 2=\mathrm{A} 3=\mathrm{A} 1=\mathrm{B} 2=\mathrm{B} 3=\mathrm{B}$ & At least one equality is an inequality \\
$\mathrm{C} 1=\mathrm{C} 2=\mathrm{C} 3=\mathrm{C}$ & \\
\hline
\end{tabular}

*(A1, B1 and C1) correspond to the parameters of the Pesadão Vermelho lineage. (A2, B2 and C2) correspond to the parameters of the Pescoço Pelado lineage. (A3, B3 and C3) correspond to the parameters of the Carijó Pesado lineage. Source: Authors.

The $\mathrm{H}_{0}$ hypothesis of the reduced model was considered adequate when $\mathrm{H}_{0}$ was rejected; i.e., $\mathrm{F} 0 \geq \mathrm{F} \alpha$ (Table 1).

To check whether the chosen models were adequate, the lack-of-fit test was applied, in accordance with the methodology of Regazzi and Silva (2004). The adopted model fit criteria were the adjusted coefficient of determination $\left(\mathrm{R}^{2}\right)$ and Durbin Watson (DW) statistics.

\section{Results and Discussion}

The equation parameter estimates (Table 2) revealed that the $A$ parameter values for the CPK lineage were higher $(A=$ $4,155)$ than those of the PSC $(A=3,223)$ and CJD lineage $(A=3,216)$, respectively. As broilers grow older, their weight gain rate (represented by the $B$ parameter) declines, which in turn prolongs the growth curve, especially for broilers of the CJD lineage. 
Table 2. Estimates of the parameters $(A, B$ and $C$ ), obtained from the Gompertz equations adjusted for body weight in the differents lineages.

\begin{tabular}{|c|c|c|c|c|c|c|c|c|}
\hline \multirow[b]{2}{*}{ Lineages* } & \multicolumn{3}{|c|}{ Parameter } & \multirow[b]{2}{*}{$\mathrm{BWe}(\mathrm{g})$} & \multirow[b]{2}{*}{ WGe $(\mathrm{g})$} & \multicolumn{2}{|c|}{ Adjustment criterion } & \multirow{2}{*}{$\begin{array}{c}\text { Lack-of-fit } \\
\text { p-value }\end{array}$} \\
\hline & $A$ & $B$ & $C$ & & & $\mathrm{R}^{2}$ & DW & \\
\hline $\mathrm{CPK}$ & 4155 & 0.0400 & 39.3996 & 1.528 & 61.14 & 0.9691 & 1.9850 & 0.999 \\
\hline PSC & 3223 & 0.0405 & 38.0486 & 1.185 & 48.01 & 0.9937 & 2.0397 & 0,077 \\
\hline CJD & 3216 & 0.0290 & 51.8035 & 1.183 & 34.30 & 0.9814 & 1.7258 & 0.325 \\
\hline
\end{tabular}

*(CPK) Pesadão Vermelho lineage; (PSC) Pescoço Pelado lineage; (CJD) Carijó Pesado lineage; BWe= Body weight estimated at the inflection point, obtained by the $\mathrm{A} / e$ derivative; $\mathrm{WG} e=$ Weight gain estimated at the inflection point, obtained by the $\mathrm{A} * \mathrm{~B} / e$ derivative; $\mathrm{DW}=\mathrm{Durbin}$ Watson. Source: Authors.

By deriving the data from each parameter, we obtain the body weight and weight gain at the inflection point, as described in Table 2. It is observed that maximum body weight at the inflection point, for CPK lineage was higher $(\mathrm{BW} e=1,528 \mathrm{~g})$ than PSC $(\mathrm{BW} e=1,185 \mathrm{~g})$ and $\mathrm{CJD}(\mathrm{BW} e=1,183 \mathrm{~g})$ lineages, indicating the broilers of that lineages are heavier and precocious, considering these animals reached the body weight at the inflection point near 39 days of age $(C=39.3996)$. To the contrary, the CJD lineage showed the highest result (52 days old) for the $C$ parameter, which represents maturity age, demonstrating that this lineage grows slower than the others.

Parametric estimates showed that the CPK lineage was superior compared to other genotypes. In the present study, with high weight to maturity (parameter $A$ ), results indicate that the lower maturity rates of PSC and CJD lineage resulted in longer times to reach their maximum body weight (BWe), between 39 and 52 days respectively and, consequently, reach higher body weights at maturity. After these ages, besides growth rates are reduced (Santos et al., 2005), since the maximum body weight $(\mathrm{BW} e)$ at the inflection point on growth curve represents the exact moment when growth rate changes from increasing to decreasing (Brito et al., 2021). Thus, interpreting the equation parameters allows inferring the lower values of maturity rate, indicating that the animal showed prolonged growth.

Based on the fitting criteria, $\mathrm{R}^{2}$ and Durbin Watson (DW), the estimated data are consistent with the observed data. The lack-of-fit test (Table 2) was not significant ( $p>0.05$ ); thus, the model equations may be considered suitable to describe the data. Overall, the coefficients of determination $\left(\mathrm{R}^{2}\right)$ obtained in this study were similar to those reported by Eleroğlu et al. (2014), who found $\mathrm{R}^{2}$ values close to 100 in experiments with free-range chickens. This suggests that the Gompertz equation was efficient in describing the body growth of the studied lineages, since the observed and estimated data exhibited good correlation according to the coefficient of determination and Durbin-Watson (DW) statistics.

After the lack-of-fit test revealed that the chosen models were suitable to describe the growth of the evaluated lineages, the estimates of body weight and weight gain at 1, 7, 14, 21, 28, 35, 42, 49, 56, 63, 70 and 77 days of age by the Gompertz model were presented (Figure 1 and 2). Body weight estimated over time (Figure 1) shows that divergence in body weight of the threelineage evaluated arise from 14 days. The earliness of CPK stood out, as those birds attained the recommended slaughter weight $(2.5 \mathrm{~kg})$ at 63 days of age, whereas the other two groups were slow.

The slaughter weight of chickens reared in a free-range system is around $2.5 \mathrm{~kg}$ at 70 days of age (MAPA, 1999; Santos et al., 2005). On this basis, the Gompertz equation parameters in the present study showed that, of all evaluated genotypes, only the CPK chickens required less time to attain the recommended slaughter weight. The PSC lineage, on the other hand, displayed a slower growth, which was estimated by weight at maturity, an older age for maximum growth, and lower weight gain at the inflection point compared with the other genotypes. 
Figure 1. Body weight ( $\mathrm{g}$ ) of lineages free-range chickens estimated from the derivative of the Gompertz equation values.

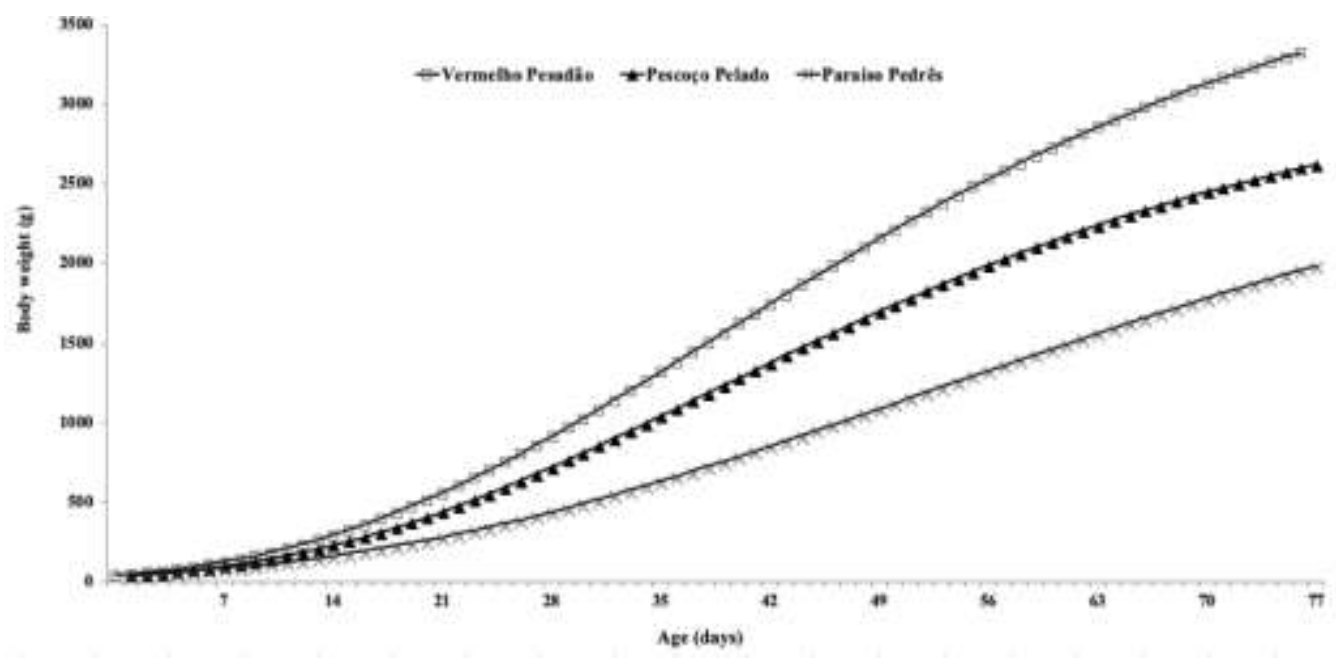

Source: Authors.

This lower growth rate is possibly related to the fact that this is a dual-purpose lineage (meat and eggs) (Albino and Moreira, 2006). Araújo et al. (2018) obtained similar results, where Carijó birds showed a lower growth rate than CPK chickens, based on derivations of Logistic model parameters. In a study led by Santos et al. (2005), with the free-range lineages CJD and PSC, the former displayed greater growth potential, according to the Gompertz model.

The CPK lineage maintained the highest body weight throughout the evaluated period, followed by PSC and CJD. For weight gain estimated as a function of age (Figure 2), the CPK birds attained maximum weight gain at 39 days, whereas the CJD chickens were later, peaking at 51 days. After those periods, daily weight gain declines, representing the inflection point of the analyzed variable.

Figure 2. Weight gain (g) of lineages free-range chickens estimated from the derivative of the Gompertz equation values.

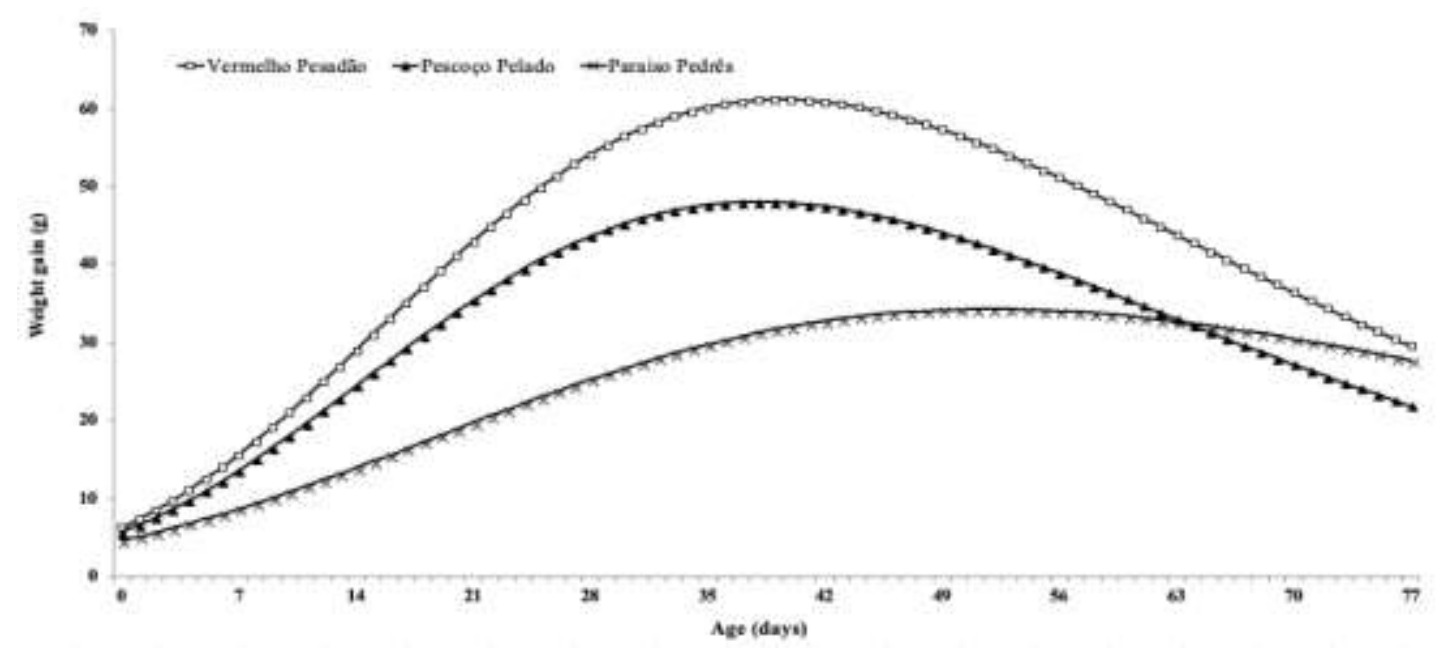

Source: Authors.

Another important factor affecting free-range chickens growth rate is related to sex. Del-Castilho et al. (2013) found difference in body weight between sexes, in which CPK males had greater growth potential, with greater muscle deposition capacity and a better-developed bone structure in relation to females; fact currently associated with sexual dimorphism. On the other hand, Santos et al. (2005) did not observe any similarity for growth potential between free-range males and females. 
Many studies report differences in the growth of free-range chicken genotypes regardless of the model used (Santos et al., 2005; Rizzi et al., 2013; Eleroğlu et al., 2014; Tavares et al., 2015). This shows that knowing the differences in growth speed between hardy lineages makes it possible to adopt management techniques that can influence bird feeding performance, the rearing system, and the choice of the genetic group to be used (Ribeiro et al., 2020). In doing so, producers can reduce slaughter age and, consequently, production costs.

Regarding nutrition, body growth is determined by protein deposition, fat and ashes, and after reaching the maximum protein deposition rates, birds showed marked reduction in deposition rate related to these body components (Nene et al., 2006), with increase in body fat deposition (Silva et al., 2017). This relationship is strictly controlled by genetic characteristics (Hen et al., 2014), but fast-growing broilers with high energy intake tend to retain dietary energy as fat, compared to protein deposition, while birds with slow growth lipid retention is lower, and protein retention is greater (Boekholt et al., 1994). Therefore, the knowledge of growth trajectory allows, in addition to the information mentioned, planning the adequate nutrition for each specific lineage.

The model parameter estimates as a function of the formulated hypotheses are described in Table 3.

Table 3. Estimates of full model ( $\Omega$ ) and reduced model ( $\omega 1, \omega 2, \omega 3$, $\left.{ }^{4} 4, \omega 5, \omega 6, \omega 7\right)$ parameters, and respective residual sum of squares (RSS) and number of residual degrees of freedom (RDF).

\begin{tabular}{|c|c|c|c|c|c|c|c|c|}
\hline & \multicolumn{8}{|c|}{ Estimate of model parameters } \\
\hline & $\Omega$ & $\omega 1$ & $\omega 2$ & $\omega 3$ & $\omega 4$ & $\omega 5$ & $\omega 6$ & $\omega 7$ \\
\hline$* A 1$ & 4154.8 & - & 4290.9 & 4520.7 & - & - & 4270.9 & - \\
\hline$B 1$ & 0.040 & 0.0437 & - & 0.0356 & - & 0.0854 & - & - \\
\hline$C l$ & 39.3978 & 37.6097 & 40.4509 & - & 64.798 & - & - & - \\
\hline$A 2$ & 3323.2 & - & 3449.2 & 3646.5 & - & - & 3521.5 & - \\
\hline$B 2$ & 0.0405 & 0.0321 & - & 0.0388 & - & 0.062 & - & - \\
\hline$C 2$ & 38.0508 & 43.475 & 39.1823 & - & 70.2793 & - & - & - \\
\hline$A 3$ & 3215.6 & - & 2539.8 & 2477.2 & - & - & 2348.8 & - \\
\hline B3 & 0.029 & 0.0244 & - & 0.037 & - & 0.0259 & - & - \\
\hline$C 3$ & 51.8034 & 59.9536 & 43.2496 & - & 73.8678 & - & - & - \\
\hline$A$ & - & 3916.7 & - & - & 7246.0 & 2583.4 & - & 3564.8 \\
\hline$B$ & - & - & 0.0381 & - & 0.0195 & - & 0.0386 & 0.0353 \\
\hline$C$ & - & - & - & 40.8256 & - & 30.6295 & 40.3036 & 41.6912 \\
\hline$R S S$ & 529065 & 552092 & 542048 & 556780 & 116083 & 423133 & 585297 & 508581 \\
\hline$R D F$ & 471 & 473 & 473 & 473 & 475 & 475 & 475 & 477 \\
\hline
\end{tabular}

*(A1, B1 and C1) correspond to the parameters of the Pesadão Vermelho lineage. (A2, B2 and C2) correspond to the parameters of the Pescoço Pelado lineage. (A3, B3 and C3) correspond to the parameters of the Carijó Pesado lineage. A = Estimate of weight at maturity (g). B = Relative growth rate at the inflection point (days) or at maximum growth. $\mathrm{C}=$ Age at the inflection point. Source: Authors.

The results of the test for the formulated hypothesis (Table 4) showed that only H0 (1), H0 (2), H0 (3) and H0 (6) were significant $(\mathrm{p}<0.05)$. Therefore, the reduced models cannot be used. 
Table 4. Results of the tests of hypotheses by the F statistics.

\begin{tabular}{lccc}
\hline Hypothesis & Measured $F$ & DF & p-value \\
\hline H0 (1): $\mathrm{A} 1=\mathrm{A} 2=\mathrm{A} 3=\mathrm{A}$ & 10.2498 & $2 ; 473$ & $49 \times 10^{-6}$ \\
H0 (2): $\mathrm{B} 1=\mathrm{B} 2=\mathrm{B} 3=\mathrm{B}$ & 5.7790 & $2 ; 473$ & $33 \times 10^{-4}$ \\
$\mathrm{H} 0$ (3): $\mathrm{C} 1=\mathrm{C} 2=\mathrm{C} 3=\mathrm{C}$ & 12.3365 & $2 ; 473$ & $59 \times 10^{-7}$ \\
$\mathrm{H} 0$ (4): $\mathrm{A} 1=\mathrm{A} 2=\mathrm{A} 3=\mathrm{A}$ & 140.6085 & $4 ; 473$ & 0.0000 \\
$\mathrm{~B} 1=\mathrm{B} 2=\mathrm{B} 3=\mathrm{B}$ & & & \\
$\mathrm{H} 0$ (5): $\mathrm{A} 1=\mathrm{A} 2=\mathrm{A} 3=\mathrm{A}$ & 823.9836 & $4 ; 475$ & 0.0000 \\
C1=C2=C3=C & 12.5151 & $4 ; 475$ & $10.99 \times 10^{-10}$ \\
H0 (6): $\mathrm{B} 1=\mathrm{B} 2=\mathrm{B} 3=\mathrm{B}$ & & & \\
$\mathrm{C} 1=\mathrm{C} 2=\mathrm{C} 3=\mathrm{C}$ & & $6 ; 477$ & 0.0000 \\
$\mathrm{H} 0$ (7): $\mathrm{A} 1=\mathrm{A} 2=\mathrm{A} 3=\mathrm{A}$ & & \\
$\mathrm{B} 1=\mathrm{B} 2=\mathrm{B} 3=\mathrm{B}$ & & & \\
$\mathrm{C} 1=\mathrm{C} 2=\mathrm{C} 3=\mathrm{C}$ & & &
\end{tabular}

*A1-A3; B1-B3; C1-C3 = equation parameters for each evaluated lineage: Pesadão Vermelho, Pescoço Pelado and Paraíso Pedrês. DF=degrees of freedom. Source: Authors.

In this way, an equation with different $A, B$ and $C$ parameters for each lineage is necessary. The equations were thus adjusted for each lineage:

For the Pesadão Vermelho lineage $Y=4,155 . e^{-e-0.0400(t-39.3996)}$

For the Pescoço Pelado lineage $\quad Y=3,223 \cdot e^{-e-0.405(t-38.0486)}$

For the Carijó Pesado lineage $\quad Y=3,215 . e^{-e-0.0290(t-51.8035)}$

This study revealed that comparing parameters with equality test, can be identified differences between growth curves of the studied strains; this means, that the hypothesis testing models similarity was rejected, demonstrating that the different strains have different parameters $A, B$ and $C$. Similar results were obtained by Morais et al. (2015), applying equality test for parameters in non-linear models, to describe growth curves in four free-range chicken lines, found that for males is possible to consider the same parameters $A, B$ and $D$ for all lines and, to describe the growth curve, only logarithmic quadratic model parameter $C$ is different for these four strains. Hence, considering the observed body weight data in the preset research, there is similarity with the information estimated by the Gompertz model, indicating good equations assertiveness to predict free-range chickens growth trajectory in each respective strains (Nene et al., 2006).

The details comparing observed and estimated body weight for the strains (Table 5) allows to infer that at 28 days of age CPK birds with observed (BWO) and estimated (BWE) body weight are similar. This comparative demonstrates that this lineage showed higher body weight than the other studied during completely productive period. At 77 days of age, the difference between BWO between CPK and CJD lineage, was about $1337 \mathrm{~g}$. 
Table 5. Observed (BWO) and estimated (BWE) body weight by the Gompertz equation at different ages for free-range chicken lines

\begin{tabular}{|c|c|c|c|c|c|c|}
\hline \multirow{2}{*}{ Age (days) } & \multicolumn{2}{|c|}{${ }^{*} \mathrm{CPK}$} & \multicolumn{2}{|c|}{ PSC } & \multicolumn{2}{|c|}{ CJD } \\
\hline & BWO (g) & BWE(g) & BWO (g) & BWE(g) & BWO (g) & BWE (g) \\
\hline 1 & 32 & 40 & 32 & 36 & 32 & 41 \\
\hline 7 & 105 & 107 & 105 & 95 & 105 & 82 \\
\hline 14 & 247 & 262 & 247 & 228 & 247 & 161 \\
\hline 21 & 561 & 515 & 479 & 438 & 292 & 279 \\
\hline 28 & 859 & 859 & 745 & 717 & 436 & 437 \\
\hline 35 & 1262 & 1261 & 1060 & 1039 & 634 & 631 \\
\hline 42 & 1660 & 1687 & 1386 & 1374 & 847 & 851 \\
\hline 49 & 2106 & 2102 & 1729 & 1696 & 1087 & 1086 \\
\hline 56 & 2483 & 2483 & 2064 & 1987 & 1318 & 1326 \\
\hline 63 & 2833 & 2816 & 2341 & 2239 & 1570 & 1560 \\
\hline 70 & 3108 & 3096 & 2567 & 2450 & 1801 & 1782 \\
\hline 77 & 3309 & 3327 & 2654 & 2621 & 1972 & 1986 \\
\hline
\end{tabular}

*(CPK) Pesadão Vermelho lineage; (PSC) Pescoço Pelado lineage; (CJD) Carijó Pesado lineage. Source: Authors.

The estimates of body weight and weight gain during the production period indicated differences in performance between the evaluated genotypes, with the low results of CJD standing out. Although the PSC and CJD strains belong to the category called 'heavy', slower growth is a characteristic of this group. These lineages have the dual ability, being widely used by small rural producers in the production of eggs and meat (Araújo et al., 2018; Albuquerque et al., 2020). The CPK lineage belongs to the 'super heavy' category, whose characteristics include higher body weight and an earlier development compared to the 'heavy' category (Lemos et al., 2018).

\section{Conclusion}

The nonlinear Gompertz model accurately describe the body growth of free-range chickens lineages evaluated. The Pesadão Vermelho, Pescoço Pelado and Carijó Pesado lineages require distinct equations to describe their growth, with parameters $A, B$ and $C$ distinct for each lineage. The Pesadão Vermelho lineage is the earliest; in other words, it reaches maturity weight at a younger age.

\section{Acknowledgments}

This study was financed in part by the Coordenação de Aperfeiçoamento de Pessoal de Nível Superior - Brazil (CAPES) - Finance Code 001, Fundação de Apoio a Pesquisa e a Inovação Tecnológica do Estado de Sergipe - Brazil (FAPITEC-SE) and by Banco do Nordeste do Brasil S.A (BNB).

\section{References}

Aisyah, S., Sembiring, I. \& Mirwandhono, E. (2018). The Analysis of Factors that Affecting the Amount of Free-Range Chicken Meat's Consumption in Langkat Regency. Journal Peternakan Integratif 6(3), 1827-1832.

Aksoy, T., Çürek, D. İ., Narinç, D. \& Önenç, A. (2021). Effects of season, genotype, and rearing system on broiler chickens raised in different semi-intensive systems: performance, mortality, and slaughter results. Tropical Animal Health and Production 53(1), 1-11.

Albino, L. F. T. \& Moreira, P. (2006). Criação de Frango e Galinha Caipira. Centro de Produções Técnicas (CPT).

Albuquerque, M. F., Garcia, A. M. L. \& Silva, I. H. L. (2021). Produção, custo e bem estar de galinha caipira da linhagem Embrapa 051 na agricultura familiar. Agricultura Familiar: Pesquisa, Formação e Desenvolvimento 14(2), 121-139.

Araújo, C. C., Rodrigues, K. F., Vaz, R. G. M. V., Conti, A. C. M., Amorim, A. F. \& Campos, C. F. A. (2018). Analysis of growth curves in different lineages of caipira broiler type. Acta Scientiarum Animal Sciences 40, e38806. 
Boekholt, H. A., Van der Grinten, P. H., Schrours, V. V. A. M., Los, M. J. N. \& Lefferinge, C. P. (1994). Effects of divergent selection for body weight on three skeletal muscles characteristics in the chicken. British Poultry Science 35, 603-614.

Brito, C. O., Cunha-Filho, O. G., Silva, C. M., Vieira, J. S., Del-Vesco, A. P., Feitosa, V. E. M., Barbosa, L. T., Ribeiro-Júnior, V. \& Fernando C. Tavernari. (2021). Estimate of body growth curve and feed intake of free-range chickens receiving different levels of digestible lysine. Spanish Journal of Agricultural Research 19(1), e0602.

Cruz, F. L., Saraiva, L. K. V., Silva, G. E., Nogueira, T. M., Silva, A. P. \& Faria, P. B. (2018). Growth and carcass characteristics of different crosses of broiler chickens reared under an alternative system. Semina: Ciências Agrárias 39, 317-328.

Del-Castilho, C. C., Santos, T. T., Rodrigues, C. A. F. \& Torres Filho, R. A. (2013). Effects of sex and genotype on performance and yield characteristics of free-range broiler chickens. Arquivos Brasileiros de Medicina Veterinária e Zootecnia 65, 1483-1490.

Eleroḡlu, H., Yildirim, A., Sekeroḡlu, A., Çoksöyler, F. N. \& Duman, M. (2014). Comparison of growth curves by growth models in slow-growing chicken genotypes raised the organic system. International Journal of Agriculture and Biology 16, 529-535.

Fradinho, M. J., Bessa, R. J. B., Ferreira-Dias, G. \& Caldeira, R. M. (2016). Growth and development of the Lusitano horse managed on grazing systems. Livestock Science 186, 22-28.

Grieser, D. O., Marcato, S. M., Furlan, A. C., Zancanela, V., Ton, A. P. S., Batista, E., Perine, T. P., Pozza, P. C., Sakomura, N. K. (2015). Comparison of growth curve parameters of organs and body componentes in meat (Coturnix coturnix coturnix) and laying-type (Coturnix coturnix japonica) quail show interactions between gender and genotype. British Poultry Science 56, 1-14.

Henn, J. D., Bockor, L., Ribeiro, A. M. L., Coldebella, A. \& Kessler, A. D. M. (2014). Growth and deposition of body components of intermediate and highperformance broilers. Brazilian Journal of Poultry Science 16(3), 319-328.

Lemos, A. V., Bittar, D. Y., Neto, O. V. \& Junior, W. G. V. (2018). Avaliação do crescimento e desempenho de diferentes linhagens de frango caipira melhorado na região de Goianésia Goiás. Pubvet 12, 1-5.

MAPA- Ministério da agricultura, pecuária e do abastecimento (1999). Registro do produto Frango caipira. Ofício circular DOI/DIPOA n. 007/99. 1999.

Michalczuk, M., Damaziak, K. \& Goryl, A. (2016). Sigmoid models for the growth curves in medium-growing meat type chickens, raised under semi-confined conditions. Annals of Animal Science 16(1), 65.

Morais, J., Ferreira, P. B., Jacome, I. M. T. D., Mello, R., Breda, F. C. \& Rorato, P. R. N. (2015). Curvas de crescimento de diferentes linhagens de frango de corte caipira. Ciência Rural 45, 1872-1878.

Moyle, J. R., Arsi, K., Woo-Ming, A., Arambel, H., Fanatico, A., Blore, P. J., Clark, F. D., Donoghue, D. J. \& Donoghue, A. M. (2014). Growth performance of fast-growing broilers reared under different types of production systems with outdoor access: Implications for organic and alternative production systems. Journal of Applied Poultry Research 23(2), 212-220.

Narinc, D., Karaman, E., Firat, M. Z. \& Aksoy, T. (2010). Comparison of non-linear growth models to describe the growth in Japanese quail. Journal of Animal and Veterinary Advances 14,1961-1966.

Neme, R., Sakomura, N. K., Fukayama, E. H., Freitas, E. R., Fialho, F. B., Resende, K. T. \& Fernandes, J. B. K. (2006). Curvas de crescimento e de deposição dos componentes corporais em aves de postura de diferentes linhagens. Revista Brasileira de Zootecnia 35, 1091-1100.

Regazzi, J. A. \& Silva, C. H. O. (2004). Testes para verificar a igualdade de parâmetros e a identidade de modelos de regressão não-linear: Dados no delineamento inteiramente casualizado. Revista de matemática e estatística 22, 33-45.

Ribeiro, M. J. B., Silva, F. F., Brito, C. O., Del Vesco, A. P., Macário, M. S., Silva, C. M. \& Barbosa, L. T. (2020). Quail growth curve model identity. Research, Society and Development, 9(10), e9439109328-e9439109328.

Rizzi, C., Contiero, B. \& Cassandro, M. (2013). Growth patterns of Italian local chicken populations. Poultry Science Journal 92, $2226-2235$.

Rostagno, H. S., Albino, L. F. T., Donzele, J. L., Gomes, P. C., Oliveira, R. F., Lopes, D. C., Ferreira, A. S. \& Barreto, S. L. T. (2011). Tabelas brasileiras para aves e suínos: Composição de alimentos e exigências nutricionais. Universidade Federal de Viçosa Press.

Sakomura, N. K., Gous, R. M., Marcato, S. M., Fernandes, J. B. K. (2011). A description of the growth of the major body components of 2 broiler chickens strains. Poultry Science Journal 90, 2888-2896.

Santos, A. L., Sakomura, N. K., Freitas, E. R., Fortes, C. M. L. S., Carrilho, E. N. V. M. \& Fernandes, J. B. K. (2005). Estudo do crescimento, desempenho, rendimento de carcaça e qualidade de carne de três linhagens de frango de corte. Revista Brasileira de Zootecnia 34, 1589-1598.

Sagrilo, E., Girão, E. S., Barbosa, F. J. V., Ramos, G. M., Azavedo, J. N., Medeiros, L. P., Araújo Neto, R. B. \& Leal, T. M. (2003). Validação do sistema alternativo de criação de galinha Caipira. Embrapa Meio Norte. Sistema de produção 1(1).

Silva, D. C. F., Arruda, A. M. V. \& Gonçalves, A. A. (2017). Quality characteristics of broiler chicken meat from free-range and industrial poultry system for the consumers. Journal of Food Science and Technology 54(7), 1818-1826.

Sousa Júnior, J. C., Rocha, F. R. T. \& Coelho, K. O. (2020). Análise bibliométrica sobre galinha e frango caipira/colonial. Research, Society and Development 9(8), e773986354-e773986354.

Souza, L. D. A., Carneiro, P. L. S., Malhado, C. H. M., \& Silveira, F. G. D. (2013). Traditional and alternative nonlinear models for estimating the growth of Morada Nova sheep. Revista Brasileira de Zootecnia 42(9), 651-655. 
Research, Society and Development, v. 10, n. 5, e48610515014, 2021

(CC BY 4.0) | ISSN 2525-3409 | DOI: http://dx.doi.org/10.33448/rsd-v10i5.15014

Souza, F. A. C., Fernandes, T. J., Moura, R. S. D., Meirelles, S. L. C., Ribeiro, R. A., Cunha, F. O. \& Muniz, J. A. (2017). Nonlinear modeling growth body weight of Mangalarga Marchador horses. Ciencia Rural 47(4), e20160636.

Tavares, F. B., Santos, M. S. V., Araújo, C. V., Costa, H. S., Loureiro, J. P. B., Lima, E. M. \& Lima, K. R. S. (2015). Performance, growth and carcass characteristics of alternatives lineages of broiler chickens created with access to paddock. Revista Brasileira de Saúde e Produção Animal 16, 420-429.

Tholon, P. \& Queiroz, A. S. (2009). Modelos matemáticos utilizados para descrever curvas de crescimento em aves aplicados ao melhoramento genético animal. Ciência Rural 39, 2261-2269. 